\title{
Confirming a Cultural Association at the La Prele Mammoth Site (48CO1401), Converse County, Wyoming
}

\author{
Madeline E. Mackie (D, Todd A. Surovell, Matthew O'Brien, Robert L. Kelly, Spencer Pelton, \\ C. Vance Haynes Jr., George C. Frison, Robert M. Yohe, Steve Teteak, Heather M. Rockwell, \\ and Shannon Mahan
}

\begin{abstract}
Archaeologists have long subjected Clovis megafauna kill/scavenge sites to the highest level of scrutiny. In 1987, a Columbian mammoth (Mammuthus columbi) was found in spatial association with a small artifact assemblage in Converse County, Wyoming. However, due to the small tool assemblage, limited nature of the excavations, and questions about the security of the association between the artifacts and mammoth remains, the site was never included in summaries of human-killed/scavenged megafauna in North America. Here we present the results of four field seasons of new excavations at the La Prele Mammoth site that confirm the presence of an associated cultural occupation based on geologic context, artifact attributes, spatial distributions, protein residue analysis, and lithic microwear analysis. This new work identified a more extensive cultural occupation including the presence of multiple discrete artifact clusters in close proximity to the mammoth bone bed. This study confirms the presence of a second Clovis mammoth kill/scavenge site in Wyoming and shows the value in revisiting proposed terminal Pleistocene kill/scavenge sites.
\end{abstract}

Keywords: Mammoth, Clovis, Paleoindian, Late Pleistocene, North America

Los arqueólogos han sometido durante mucho tiempo a los sitios de caza y destazamiento de megafauna de Clovis al más alto nivel de escrutinio. En 1987, se encontró un mamut colombino (Mammuthus columbi) en asociación espacial con un pequeño conjunto de artefactos en el condado de Converse, Wyoming. Sin embargo, debido al pequeño conjunto de herramientas, la naturaleza limitada de las excavaciones y a las preguntas sobre la seguridad de la asociación entre los artefactos y los restos de mamuts, el sitio nunca se incluyó en los resúmenes de los sitios de caza y destazamiento de megafauna de Norteamérica. Aquí presentamos los resultados de cuatro temporadas de campo de nuevas excavaciones en el sitio La Prele Mammoth que confirman la presencia de una ocupación cultural asociada y basada en el contexto geológico, atributos de artefactos, distribuciones espaciales, análisis de residuos de proteínas y análisis microscópico de huellas de uso lítico. Este nuevo trabajo identificó una ocupación cultural más extensa que incluye la presencia de múltiples grupos de artefactos discretos en una proximidad espacial cercana a la cama de huesos de mamut. Este estudio confirma la presencia del segundo sitio de caza y destazamiento de mamuts de Clovis en Wyoming y muestra el valor de retornar a sitios de caza y destazamiento propuestos del Pleistoceno Terminal.

Palabras clave: mamut, Clovis, Paleoindio, Pleistoceno, Norteamérica

Madeline E. Mackie (mmackie@ uwyo.edu, corresponding author), Todd A. Surovell, Robert L. Kelly, and George C. Frison - Department of Anthropology, University of Wyoming, Department 3431, 1000 East University Avenue, Laramie, WY 82071, USA

Matthew O'Brien — Department of Anthropology, California State University at Chico, 400 West First Street, Chico, CA 95929, USA

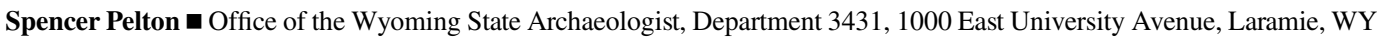
82071, USA

C. Vance Haynes Jr. $\square$ School of Anthropology and Geosciences, University of Arizona, 1009 East South Campus Drive, Tucson, AZ 85721, USA

Robert M. Yohe, and Steve Teteak $\square$ Department of Anthropology, California State University at Bakersfield, 9001 Stockdale Highway, Bakersfield, CA 93311, USA

Heather M. Rockwell a Wyoming State Historic Preservation Office, 2301 Central Avenue, Cheyenne, WY 82002, USA Shannon Mahan — U.S. Geological Survey, Luminescence Geochronology Laboratory, Denver Federal Center Box 25046 MS 974, Denver, CO 80225, USA

American Antiquity 85(3), 2020, pp. 554-572

Copyright $(2020$ by the Society for American Archaeology doi:10.1017/aaq.2020.8 
$\mathbf{I}$ n the early twentieth century, Aleš Hrdlíčka and others established three requirements necessary to prove a Pleistocene-aged human presence in the New World: (1) artifacts or remains that were clearly human, (2) artifacts in indisputable context (direct association), (3) control over chronology (undisturbed stratigraphy; Adovasio and Page 2009:99; Haynes 1969; Meltzer 2015a). These stringent, yet reasonable, requirements were met in 1927 when prominent scientists A. V. Kidder and Frank H. H. Roberts confirmed the association of artifacts with extinct bison remains in Folsom, New Mexico. Soon after, archaeologists discovered what would later be classified as Clovis points associated with mammoth bones at the Dent site in Colorado (Figgins 1933). Starting with these discoveries of fluted points and extinct fauna, the hallmark of the Clovis culture has become the hunting of now-extinct Pleistocene fauna (Kornfeld 2007; Meltzer 2015a). While many archaeologists question the view of Clovis as big-game specialists (Cannon and Meltzer 2004, 2008), there is universal acceptance in the field that Clovis hunters did, at least occasionally, hunt megafauna (Haynes and Hutson 2013; Kornfeld 2007; Surovell and Waguespack 2009). Understanding the number and nature of Pleistocene megafauna kills/scavenge sites is therefore vital to understanding North America's earliest widespread inhabitants.

Archaeologists have subjected Paleoindian kill/scavenge sites to intense scrutiny, especially so for sites containing proboscidean (Mammuthus sp., Mammut americanum, Cuvieronius sp.) remains (Cannon and Meltzer 2004; Frison and Todd 1986; Grayson and Meltzer 2002, 2015; Haynes 1988, 1991, 2002, 2007a; Haynes and Huckell 2007; Haynes and Krasinski 2010; Haynes and Stanford 1984; Hofman 2001; Kreutzer 1988; Meltzer and Mead 1985; Saunders and Daeschler 1994; Waguespack and Surovell 2003). The skepticism of a human presence at bone bed sites is warranted, since natural death sites can be difficult to distinguish from kill/scavenge sites (e.g., Haynes 1991, 2007b; Haynes and Klimowicz 2015; Lyman 1994; Todd 1987; Todd and Rapson 1999). This high bar for acceptance, however, potentially rejects true associations and consequently affects both interpretations of Clovis lifeways
(Cannon and Meltzer 2004, 2008; Haynes 2002; Surovell and Waguespack 2009) and the debate surrounding the cause of megafaunal extinctions in the Americas (for review, see Meltzer 2015b; Waguespack 2013). Accordingly, sites containing the remains of extinct megafauna require close attention to taphonomy and site formation to determine human involvement.

Following Hrdlícka and William Henry Holmes, archaeologists ask that megafauna kill/ scavenge sites meet three requirements: (1) contemporaneity of human and megafauna remains, (2) direct association between human activity and megafauna remains, and (3) evidence for use of megafauna remains (e.g., cutmarks, breakage; Grayson and Meltzer 2002, 2015; Haynes and Stanford 1984). Researchers have used these criteria to scrutinize possible megafauna kill/scavenge sites (Cannon and Meltzer 2004; Grayson 1984; Grayson and Meltzer 2002, 2015; Haynes 1988, 2002; Haynes and Stanford 1984; Surovell and Waguespack 2009).

Here we apply these criteria to a previously questioned mammoth kill site, the La Prele Mammoth site. The site's initial excavations (Walker et al. 1988) left doubt regarding the association of artifacts with the mammoth remains (Byers 2002; Grayson and Meltzer 2002). However, our four seasons of investigations show that the La Prele site meets the three criteria, resolves previous doubts about the site, and contains an undeniable association between evidence of human activity and mammoth remains.

\section{The La Prele Mammoth Site}

The La Prele Mammoth site (48CO1401) is buried in an alluvial terrace of La Prele Creek, a tributary of the North Platte River, near the town of Douglas in Converse County, Wyoming (Figures 1-2). Initially called the Hinrichs and later the Fetterman Mammoth, the site was discovered in fall 1986 by two Douglas locals, Mike Earnst and William Hinrichs. The following spring a crew led by Dr. George Frison tested the site with an approximately $3 \times 4 \mathrm{~m}$ block. Frison and crew recovered the partial remains of a mammoth (Mammuthus sp.) and a small artifact assemblage that included a stone tool, a possible hammerstone, and two in situ flakes 


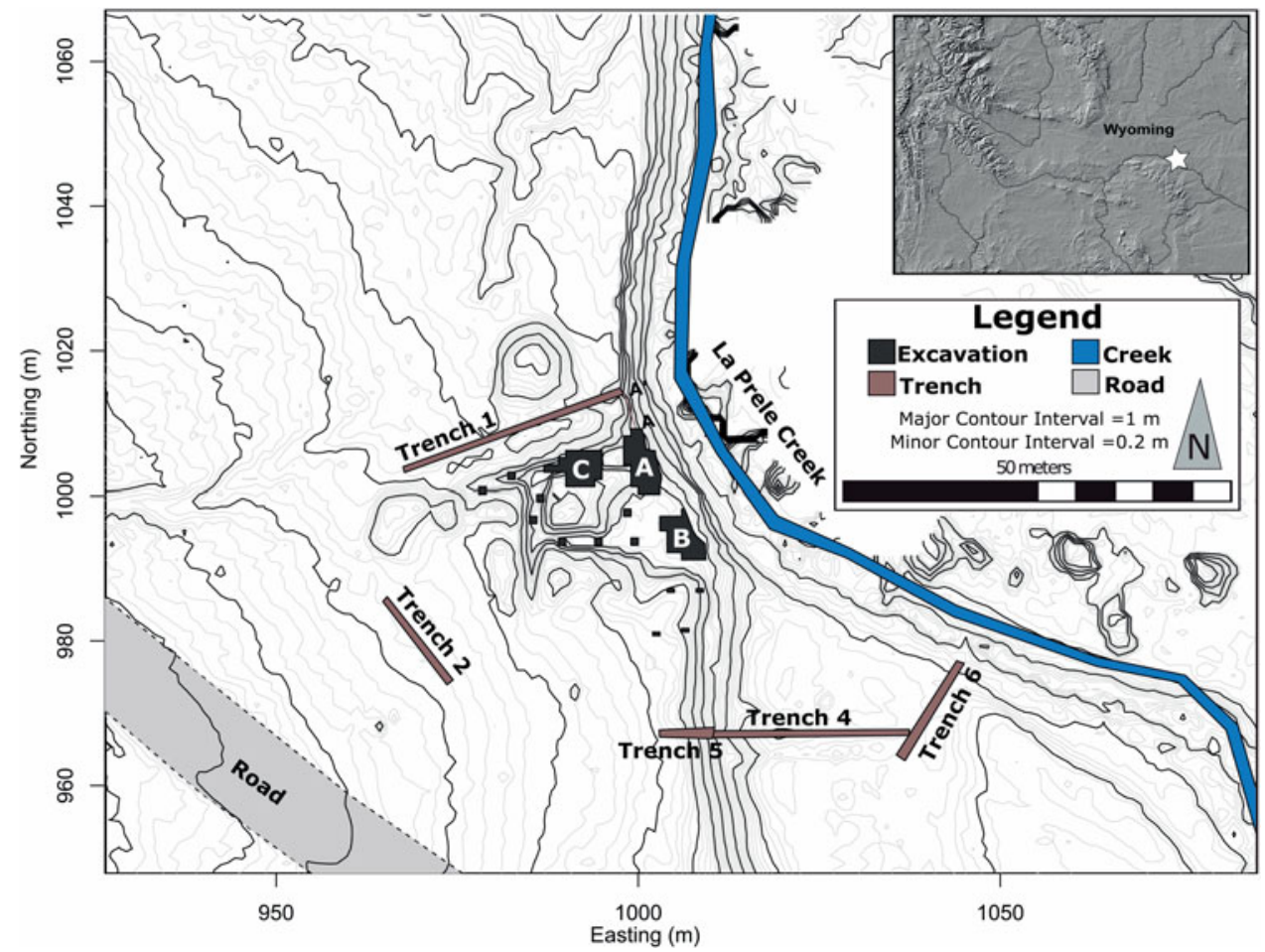

Figure 1. Local topographic map of the La Prele Mammoth site identifying geologic trenches and excavation areas. Major contours are at $1 \mathrm{~m}$ intervals, while minor contours are at $20 \mathrm{~cm}$. Note that some of the topography in the immediate area of the excavation is due to backhoe work to expose archaeological strata, and topographic lines were not rendered in the northeast portion of the map due to heavy brush (topographic map created by Randy Haas). (Color online)

(Walker et al. 1988). The mammoth remains consisted predominantly of axial elements, the other portions having perhaps washed down the creek before the site was identified (Byers 2002:Table 1). The artifact assemblage grew when seven flakes were found in the sediments surrounding the mammoth bones in their plaster casts (Byers 2002; Walker et al. 1988). ${ }^{1}$ The initial excavators concluded that "these flakes would have been deposited at the same stratigraphic level as the ribs, lending credence to the association of the stone biface [flake tool] and flake found during excavation and the mammoth bone" (Walker et al. 1988:159). Unfortunately, for the next 30 years the site sat untouched because of a dispute with the landowner.

In the intervening years, Byers (2002) cast doubt on the original interpretation of cultural association based on analysis of the 1987 field notes and assemblage. The lack of butchery marks and the close anatomical position of the bones were consistent with a natural death event. Bone weathering patterns suggested that the mammoth remains were partially buried at least twice before being completely covered, leaving the door open for the subsequent deposition of unassociated artifacts (Byers 2002:432-435). Finally, slight elevation differences between the bone bed and in situ artifacts found during excavation pointed to separate depositional events for the artifacts and mammoth remains (Byers 2002:Figure 11; Walker et al. 1988). Byers hypothesized that during one of the partial burial events, artifacts from a later or nearby occupation were washed into the bone bed. This hypothesis was also consistent with the small size and quantity of the artifact assemblage. While none of these analyses is damning on its own, together they cast doubt on human involvement with the mammoth (Byers 2002).

A change in landowners allowed us to return to the site in 2014 to address the possibility of 


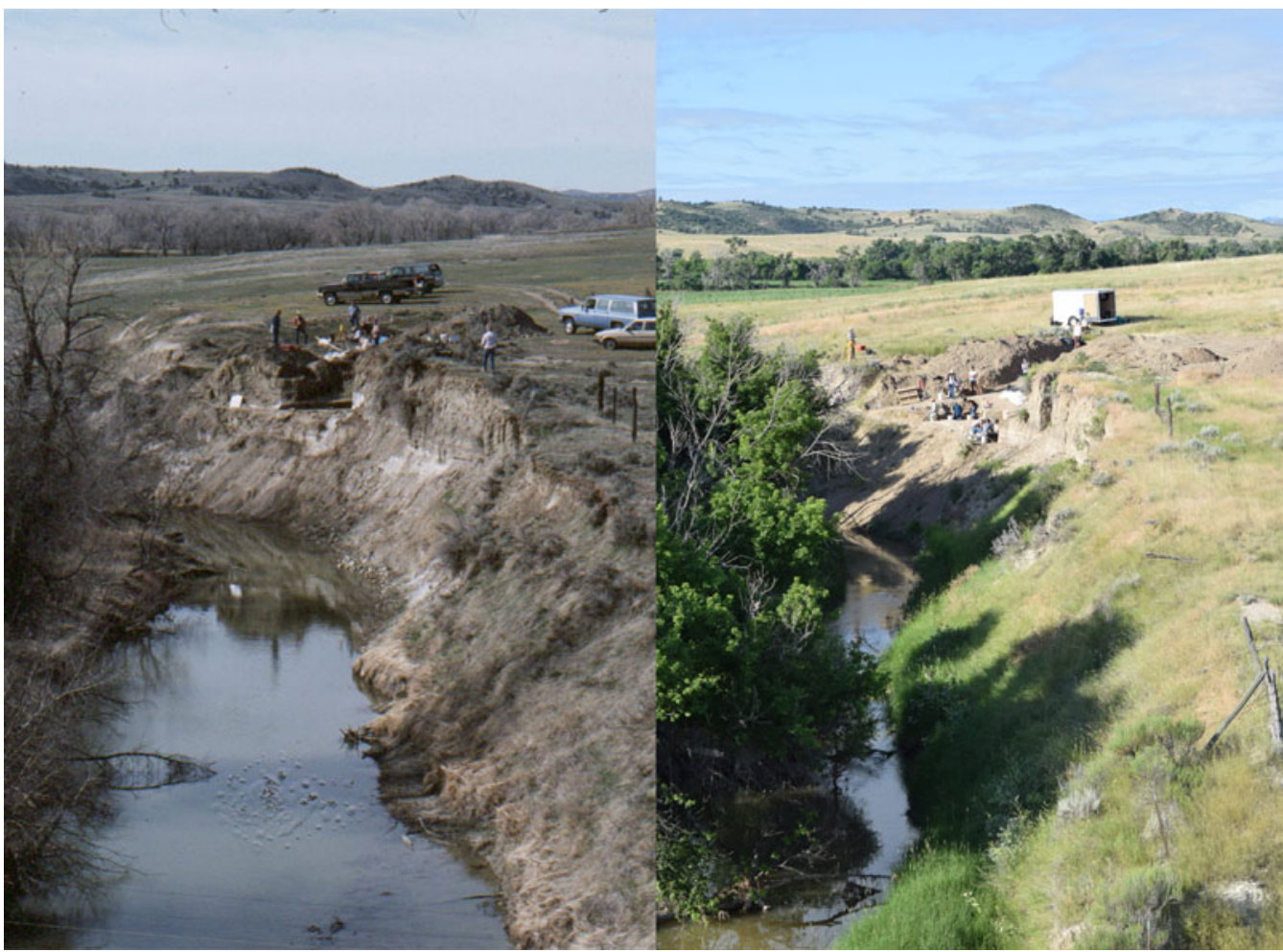

Figure 2. Overview of the 1987 and 2015 excavations at the La Prele Mammoth site. The site has been actively eroding since its discovery, and approximately $1.5 \mathrm{~m}$ of Block A has been lost. (Color online)

a cultural presence there. After relocating the 1987 block, we expanded the original excavations and tested additional portions of the site. Units were excavated in $50 \times 50 \mathrm{~cm}$ quadrants in $5 \mathrm{~cm}$ levels, and all materials recovered in situ, regardless of size, were point plotted using a total station. All sediments were wet screened with $1 / 16$-inch mesh, and screen matrix was picked in the laboratory after initial picking in the field. Portions of the site contained calcium carbonate concretions large enough to obscure artifacts. These carbonate-rich sediments were treated with acetic acid and picked for artifacts, and gravels were weighed by size. Since an understanding of the site's formation processes was critical to addressing the previous questions, we excavated several geologic trenches that were profiled and dated using radiocarbon and optically stimulated luminescence.

Encouraged by the discovery of additional cultural materials and faunal remains, we completed four seasons of excavations at the site
(2014 to 2017). In total we have excavated just under $100 \mathrm{~m}^{2}$ along with six geologic trenches (Figure 1). New excavations include the expansion of the 1987 bone bed (Block A), two associated artifact concentrations (Blocks B and C), and 11 test units. We have identified multiple activity areas surrounding the mammoth and recovered more than 1,700 pieces of chipped stone, $500+$ bone fragments, and 1,600+ ocher pieces. Here we focus on the evidence supporting the cultural association with the mammoth remains, while future publications will present the details and interpretations of the new artifact assemblages found at the La Prele Mammoth site.

\section{Geologic and Chronological Setting}

The La Prele Mammoth is buried within a $7 \mathrm{~m}$ alluvial terrace of the La Prele Creek (Figure 2). Terrace sediments span circa 20,000-45,000 cal BP and include alluvial, colluvial, and eolian deposits with intermittent episodes of soil 


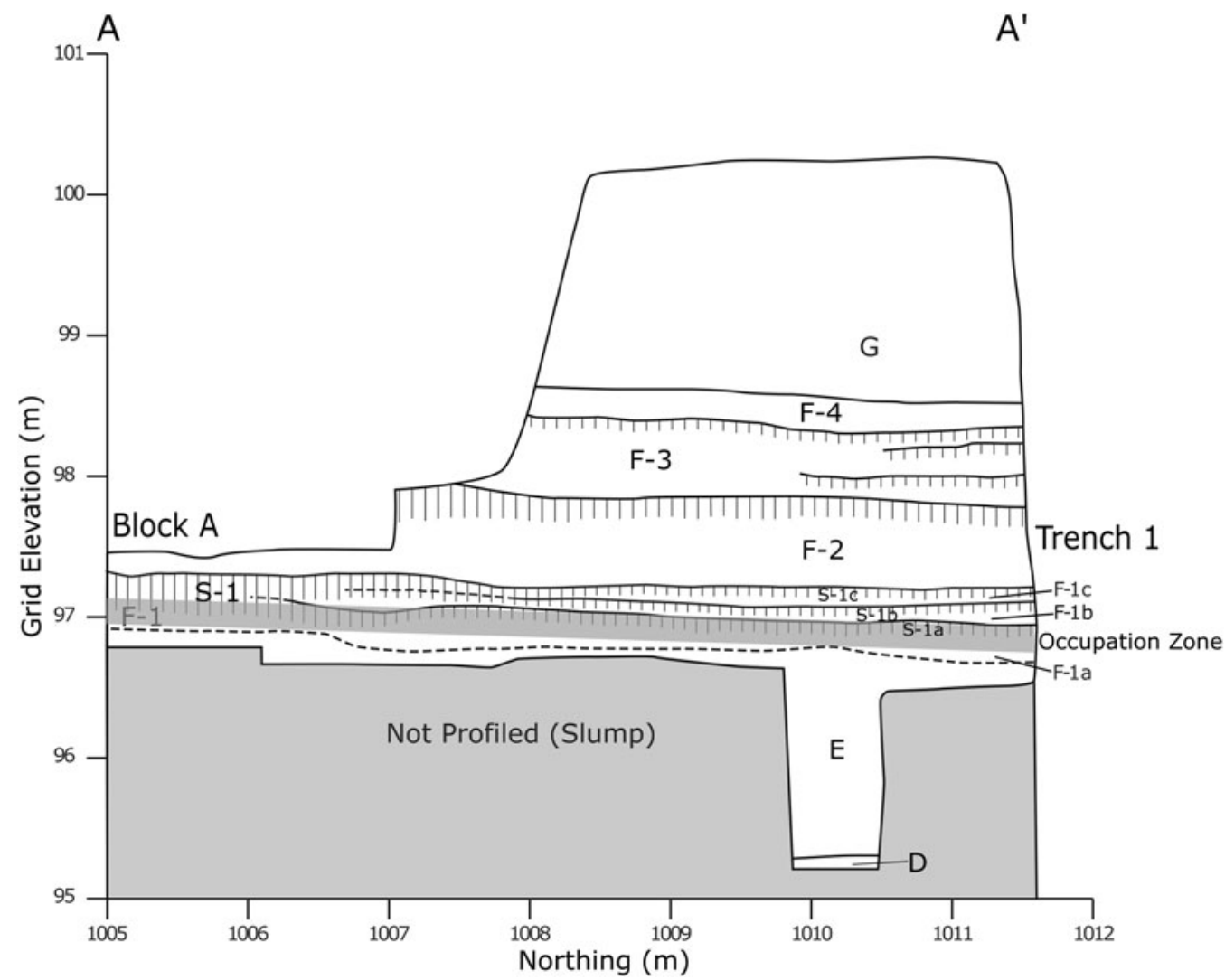

Figure 3. Profile of cleaned terrace face between Block $A$ and Trench 1 in 2015. The archaeological deposits sit at the base of $\mathrm{S}-1$, which welds into a single soil in the center of this profile just north of Block $\mathrm{A}$. Strata descriptions can be found in Supplemental Text 1.

formation (Supplemental Text 1; Supplemental Tables 1-2). The only known archaeological deposits at the locality are in the same stratigraphic horizon as the mammoth, at the lower margin of a buried A-horizon (S-1) within the overbank sediments in which it formed (F-1; Figure 3). Based on texture, sorting, and bedding, we determined that the sediments underlying (F-1) and immediately overlying (F-2) are low-energy overbank flood deposits, not colluvial as previously hypothesized (Albanese 2000; Byers 2002). While the S-1 paleosol presents as a pedogenic unit within the excavated portion of the site, it is likely the product of three A-horizons that weld just north of Block A (Figure 3). This is consistent with the mammoth being buried in three stages as hypothesized by Byers (2002) based on bone weathering patterns.
Site dating has been complicated by the presence of young contaminants. Originally, Byers (2002:421) reported two early Holocene dates on the mammoth bone, $8890 \pm 60 \mathrm{BP}$ (CAMS-74661) and 9060 \pm 50 BP (CAMS72350; Table 1). While the close range of the dates allowed for some confidence, Byers acknowledged that these dates were young for a mammoth site and could have been affected by contamination. Since 2014, an additional 10 dates from two different portions of the site directly or indirectly date the occupation (Table 1), two of which were recently published by Devièse and colleagues (2018). Dated materials include four bone fragments (two mammoth, two large mammal), two calcined bone samples, two pieces of charcoal, and two samples of soil organic matter. The distribution of the dates confirms the presence of contaminants, as the six 
Table 1. Summary of Radiocarbon Dates That Directly or Indirectly Date the Occupation.

\begin{tabular}{|c|c|c|c|c|c|c|c|c|}
\hline $2 \sigma$ Calibrated Age (BP) & $1 \sigma{ }^{14} \mathrm{C}$ Age (BP) & $\delta^{13} \mathrm{C}(\% o)$ & Lab No. & Area & Collection Year & Material & Fraction & Source \\
\hline \multicolumn{9}{|l|}{ Direct Dates } \\
\hline $10,196-9769$ & $8890 \pm 60$ & & CAMS-74661 & Block A & 1987 & Mammoth bone & Gelatin & Byers 2002:421 \\
\hline $10,300-10,157$ & $9060 \pm 50$ & & CAMS-72350 & Block A & 1987 & Mammoth bone & $\mathrm{KOH}$-extracted collagen & Byers 2002:421 \\
\hline $12,721-12,532$ & $10,654 \pm 58$ & -17.9 & AA108894 & Block B & 2016 & Large-mammal bone & Ultrafiltered collagen & This report \\
\hline $12,738-12,658$ & $10,760 \pm 30$ & & UCIAMS-40174 & Block A & 1987 & Mammoth bone & Gelatin & Devièse et al. 2018:Table 8 \\
\hline $12,762-12,597$ & $10,776 \pm 59$ & -16.4 & AA108895 & Block B & 2016 & Large-mammal bone & Ultrafiltered collagen & This report \\
\hline $12,922-12,716$ & $10,965 \pm 30$ & & UCIAMS-206764 & Block A & 1987 & Mammoth bone & XAD hydrolysate $^{\mathrm{a}}$ & Devièse et al. 2018:Table 8 \\
\hline $13,074-12,779$ & $11,066 \pm 61$ & -20.3 & AA108893 & Cutbank & 1986 & Mammoth bone & Ultrafiltered collagen $^{\mathrm{a}}$ & This report \\
\hline $13,290-12,765$ & $11,190 \pm 130$ & -23.0 & AA107104 & Block B & 2015 & Calcined bone & Apatite carbonate $\mathrm{e}^{\mathrm{a}, \mathrm{b}}$ & This report \\
\hline $13,041-12,757$ & $11,035 \pm 50$ & -22.7 & OxA-X-2736-14 & Block A & 1987 & Mammoth bone & Hydroxyproline $^{\mathrm{a}}$ & Devièse et al. 2018:Table 10 \\
\hline $17,330-16,640$ & $13,997 \pm 90$ & -19.7 & AA109297 & Block B & 2016 & Calcined bone ${ }^{\mathrm{c}}$ & Apatite carbonate $^{\mathrm{b}}$ & This report \\
\hline \multicolumn{9}{|l|}{ Indirect Dates } \\
\hline $12,982-12,720$ & $10,969 \pm 52$ & -25.1 & AA105498 & Block A & 2014 & Charcoal $^{\mathrm{d}}$ & Humins & This report \\
\hline $12,803-12,696$ & $10,873 \pm 35$ & -26.0 & AA107604 & Block B & 2015 & Charcoal $^{\mathrm{d}}$ & Humins & This report \\
\hline $12,413-12,061$ & $10,382 \pm 40$ & -25.4 & AA105496 & Block B & 2014 & Soil organic matter & Humins & This report \\
\hline $12,245-11,982$ & $10,323 \pm 39$ & -25.5 & D-AMS 004329 & Cutbank & 2013 & Soil organic matter & Humins & This report \\
\hline
\end{tabular}

Note: Dates were calibrated using OxCal with the IntCal 13 calibration curve (Reimer et al. 2013). All radiocarbon dates from the site can be found in Supplemental Table 1.

${ }^{a}$ Dates considered most reliable by the authors.

${ }^{\mathrm{b}}$ Accuracy established by Chatters et al. 2017.

${ }^{\mathrm{c}}$ Anomalous date.

${ }^{\mathrm{d} I n d i c a t e s ~ t h e ~ a g e ~ o f ~ t h e ~ s t r a t i g r a p h i c ~ u n i t, ~ a s ~ c h a r c o a l ~ f r a g m e n t s ~ c a n n o t ~ b e ~ d i r e c t l y ~ a s s o c i a t e d ~ w i t h ~ t h e ~ o c c u p a t i o n . ~}$ 
dates on mammoth bone produced the youngest as well as some of the oldest dates on the site. We also have one date on calcined bone, $13,997 \pm 90 \mathrm{BP}$ (AA109297), that is anomalously old, for which we do not have a good explanation of its age.

Because contamination of bone collagen almost always produces radiocarbon dates that are too young, we argue that the oldest mammoth bone collagen dates and a calcined bone date from Block B are closest to representing the true age of the site. These four oldest direct dates produce a statistically homogeneous subset determined by pairwise $t$-tests (Long and Rippeteau 1974) after calibration. Those include two dates first reported herein on ultrafiltered collagen from a recovered mammoth rib $(11,066 \pm$ 61 BP, AA108893) and a calcined bone date from Block B $(11,190 \pm 130$ BP, AA107104) from a hearth-centered activity area (Mackie et al. 2020). We also include two dates published by Devièse and others (2018), one hydroxyproline date on collagen from a mammoth vertebra from the 1987 excavation $(11,035 \pm 50$ BP, OxA-X-2736-14), and a sample of XAD-purified protein hydrolysate from the same vertebra $(10,965 \pm 30$, UCIAMS206764). After calibration and averaging by the Long and Rippeteau (1974) method, our best estimate for the age of the site is $12,846 \pm 29$ cal BP, placing the La Prele Mammoth site within the Clovis time period as defined by Waters and Stafford (2007). Further confirmation of this age estimate comes from two soil organic matter dates on the S-1 paleosol dating the soil formation to a few hundred years after the mammoth's death (Table 1). The discovery of a nearly complete fluted projectile point in the same stratigraphic level as the mammoth approximately 20 $m$ to the southeast of the bone bed confirms the cultural affiliation as Clovis.

\section{Testing Cultural Association}

There are a few patterns we expect to see at the $\mathrm{La}$ Prele Mammoth site if the cultural activities and mammoth remains are associated. First, there should be a mechanism to account for the vertical movement of materials on-site that would explain the elevation differences between the
1987 lithic artifacts and the bone bed. Second, there should be little to no evidence of horizontal disturbance, as this would make the redeposition of artifacts from a secondary source unlikely. Third, if the cultural materials and mammoth bone are associated, they must have been deposited at the same time and would have been subjected to the same postdepositional processes. Finally, there should be some direct evidence of interaction between the cultural materials and the mammoth remains. If these four lines of evidence are present, we can reasonably conclude that there is an association between the cultural component and the mammoth bone at the site. In order to test these four lines of evidence we look at three components of the site: (1) geologic context, (2) provenience of bone and artifacts, and (3) evidence of direct association.

\section{Geologic Context}

The single strongest piece of evidence for questioning a cultural association with the mammoth remains is the elevation difference between the four in situ artifacts and the mammoth bone (Byers 2002). Byers noted that this discrepancy could be accounted for by "several geomorphological processes whose signatures are not readily identifiable. . . including bioturbation, frost heaving, and soil compaction" (2002:437). During the last four field seasons we have gained a better understanding of the geologic context and setting of the La Prele Mammoth site through excavations and geologic trenching. The exposure of a larger stratigraphic profile has allowed for a more detailed reconstruction of the Pleistocene surface. This greater understanding of the geologic context of the artifactbearing deposits is useful for evaluating the first two lines of evidence: the presence or means for vertical and horizontal disturbances on-site.

Bioturbation. Back plots of in situ artifacts from Block A and Block B show that artifacts are stratigraphically associated with the mammoth remains (Figure 4). In all portions of the site the archaeological material is only associated with upper stratum F-1 and the S-1 paleosol. Although bioturbation had not been previously noted on-site, it is extensive, with visible 


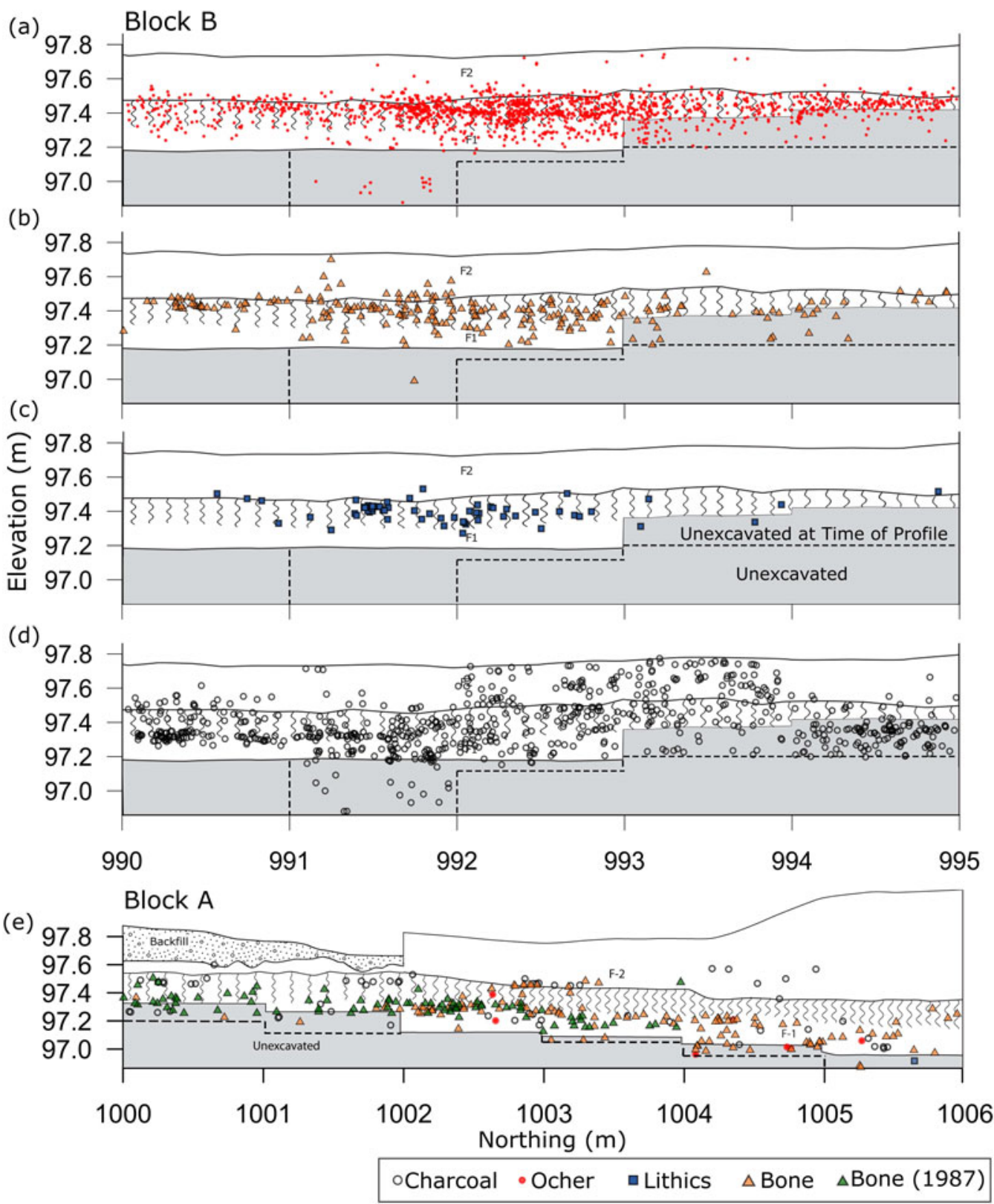

Figure 4. West wall profiles of excavation Blocks A and B with artifact back plots overlain. Deepest extent of excavation within the excavation block east of each profile is indicated by the dashed line. (Color online)

mottling of the F-1 sediment and S-1 paleosol across the site (Figure 5). Artifact back plots from several site areas show the effects of bioturbation. In Block B, small numbers of artifacts appear as deep as $55 \mathrm{~cm}$ beneath the postulated occupation surface, but most materials are spread throughout a $35 \mathrm{~cm}$ zone. Based on the relatively small size of the majority of krotovinas $(<3 \mathrm{~cm})$, most of the bioturbation appears to be the result of insect and small rodent activity (Figure 5). Given this extreme bioturbation, it is unsurprising that a small number of the artifacts from 1987 were found at slightly higher elevations than the bone bed. 


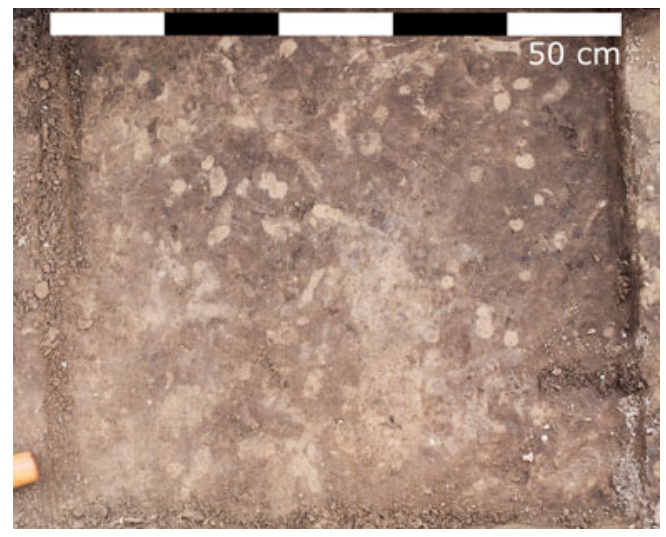

Figure 5. Typical extent of bioturbation with intermixing of the F-1 and S-1 strata. (Color online)

Reconstruction of the Pleistocene Surface. Byers (2002:427) suggested that the artifacts could have been deposited by slope-related processes. This hypothesis was based on the modern ground surface west of the site, which has a gradual slope extending from the site to a nearby strath terrace of the North Platte (Figure 1). However, our larger exposures of the paleosurface show that the Pleistocene surface had relatively little slope. The F-1/F-2 contact drops only approximately $15 \mathrm{~cm}$ over $16 \mathrm{~m}$ from south to north (N990 to N1006; Figure 4), and from west to east the site drops $20 \mathrm{~cm}$ over $21 \mathrm{~m}$ (Supplemental Text 1; Supplemental Figure 1). Thus, slopes average just under a centimeter of elevation change per meter. Redeposition of artifacts by slope-related processes is not possible under these circumstances (Fanning and Holdaway 2001; Poesen et al. 1998).

Based on taphonomic analysis of bone weathering stages, Byers (2002) concluded that the mammoth was likely buried by multiple small flood events. While the S-1 paleosol in the excavation blocks is welded into a single cumulic A-horizon, the S-1 soil separates into three thin A-horizons (Soils 1a to 1c) north of Block A (Figure 3; Supplemental Text 1). Byers (2002) attributes the artifacts' position higher than the bone as possible evidence for their deposition following one of these small flood events. We propose that the artifacts were shifted through bioturbation, as the lack of slope on the Pleistocene surfaces makes artifact redeposition over long distances unlikely. While we agree that the mammoth was buried in three small flood events, we do not think that those events were responsible for the association between the cultural materials and the mammoth remains.

\section{Assemblage Composition and Spatial Patterns}

The presence of bioturbation offers a plausible mechanism for vertical separation between artifacts and the bone bed, but it does not indicate contemporaneity of the human occupation and mammoth remains. The radiocarbon ages from the occupation show that both cultural materials (e.g., calcined bone) and mammoth remains have overlapping ages (Table 1). However, due to an unidentified source of contamination that is younger than the sample, the consistency between dates is by no means conclusive. Instead, we look for indications of contemporaneity using artifact distributions and assemblage attributes. We use three different tests: (1) vertical movement of different materials, (2) identification of artifact clusters, and (3) comparison of lithic attributes between blocks.

Vertical Distribution Analysis. The first test for contemporaneity between cultural and faunal remains examines the vertical dispersal of materials by bioturbation. If the cultural materials and mammoth are associated, they would have been deposited at the same time and been subjected to the same postdepositional processes. Therefore, we should expect similar bone and artifact vertical distributions by bioturbation. For this analysis, point-plotted cultural artifacts (lithics and ocher) are compared with point-plotted bone. Unfortunately, the exact elevation of the mammoth bone bed excavated in 1987 could not be reconstructed with sufficient confidence (within $3 \mathrm{~cm}$ ) to be included in this analysis. ${ }^{2}$ Only those bones recovered from recent excavations are included, including several larger pieces of mammoth bone (partial rib, tarsal, unidentified large fragments) and many small bone fragments. Although the majority of the new bone assemblage is too small for species identification, many pieces are likely mammoth, so it is used here to represent the mammoth provenience. The slope on the La Prele site is gradual enough that is it unlikely to redeposit artifacts, but it is large enough that raw artifact elevations 

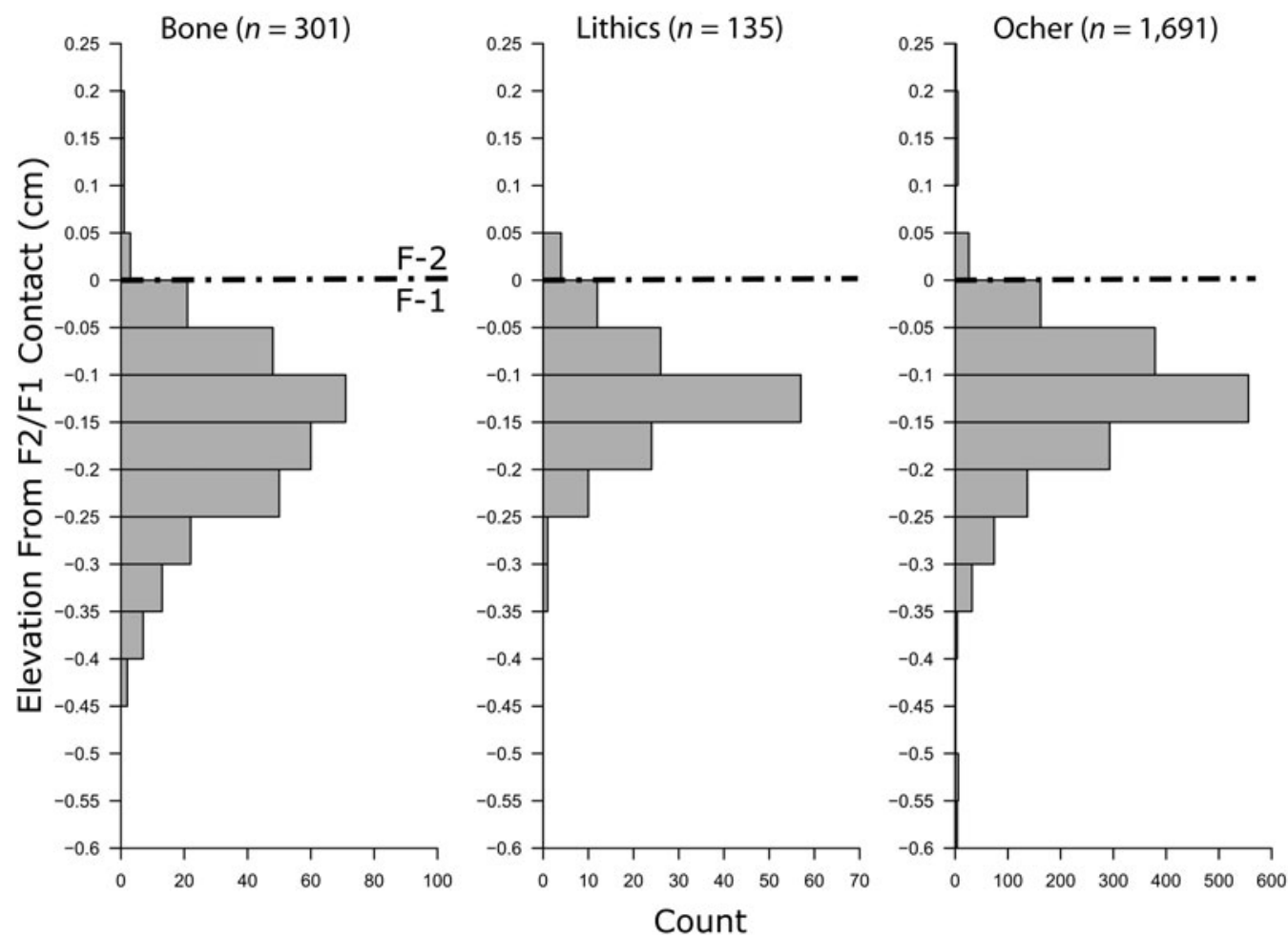

Figure 6. Dispersal of artifacts relative to the F-2/F-1 contact. The dashed line indicates the strata contact at elevation zero.

cannot be directly compared within or between excavation blocks. Instead, all mapped bone and artifact elevations can be standardized to the F-2/F-1 contact, since it is a consistent lithostratigraphic contact that mirrors the topography of the paleosurface. We digitized the F-2/F-1 contact elevation on 17 stratigraphic profiles across the site and subtracted each artifact's elevation from the closest mapped F-2/F-1 contact elevation. The mapped stratigraphic contacts lie within approximately $5 \mathrm{~m}$ of each point-plotted artifact/bone/ocher (Figure 6).

The distributions of all three material classes are remarkably similar, with modes at 10-15 $\mathrm{cm}$ beneath the F-2/F-1 stratigraphic contact. This marks the likely position for the occupation and is consistent with the highest artifact concentrations occurring in or near the lower part of the paleosol (S-1; Figure 4). Both the lithics and ocher are distributed across approximately 35 $\mathrm{cm}$ vertically, while most of the bone is spread over $50 \mathrm{~cm}$ (Figure 6). We suspect that the bone has a larger distribution because not all the fragments present are associated with the archaeological occupation, although all obvious microfauna remains were excluded from this analysis. In either case, all three distributions are similarly dispersed, suggesting that the artifacts and the majority of bone were deposited at the same time and have been subjected to the same postdepositional processes.

Horizontal Spatial Distributions. Spatial distributions can also help determine whether artifacts were redeposited on the site by establishing the horizontal spatial integrity of the La Prele deposits. If materials were disturbed or redeposited onto the site, we would expect to see a homogeneous distribution of artifacts across the site from their source (Gregg et al. 1991). Based on the artifact frequency distributions, artifacts are not distributed homogeneously across the site; instead, each block encompasses distinct clusters with areas of low artifact densities separating clusters (Figures 7-8). 

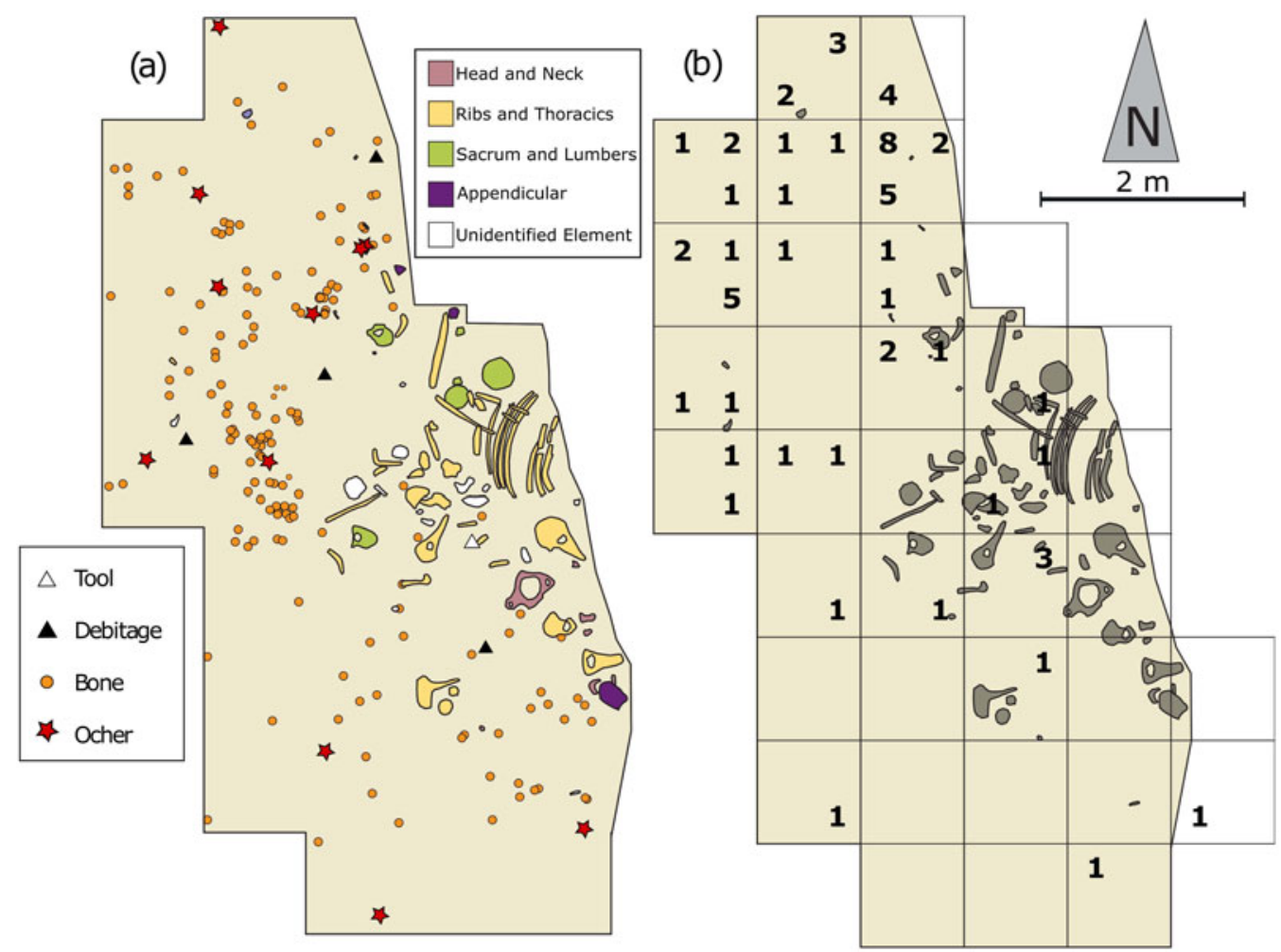

Figure 7. Map of Block A including 1987 and recent excavations: (a) artifact point plots and mammoth elements coded by portion; (b) lithic totals as of 2019 by $50 \times 50 \mathrm{~cm}$ quadrant. (Color online)

This heterogeneous artifact distribution suggests that the horizontal spatial distributions on-site are relatively intact and that redeposition is not responsible for the artifacts found in the bone bed.

We can also test whether the artifacts are spatially associated with the mammoth remains in Block A (Figure 7). A simple test is to calculate the average distance of lithic artifacts from the closest large faunal element and compare that with the average distance seen in a random (null) artifact distribution (Giusti et al. 2018). If artifacts are associated with mammoth remains, we would expect the distance between the observed artifact distribution and the closest bone elements to be smaller than the distance from the randomly generated artifact locations to mammoth elements. To run the analysis, we took the number of artifacts recovered as of 2019 from Block A $(n=63)$ and randomized their location within their respective $50 \times 50 \mathrm{~cm}$ quadrants (Figure 7). The same number of artifacts were randomly plotted across the entire excavation block to create random distributions. The average distance of the observed and random artifact distributions to mammoth elements was recorded, and the analysis was repeated. Twenty thousand iterations confirm that the observed assemblage $(\bar{x}=49.6 \mathrm{~cm})$ was significantly closer ( $p=.0454)$ than the randomly distributed artifacts $(\bar{x}=60.9 \mathrm{~cm})$ to faunal remains. This supports the hypothesis that artifacts were deposited in association with the faunal remains and indicates that horizontal distributions are relatively intact on-site.

The close spatial association of the mammoth remains and artifacts is also significant as the $\mathrm{La}$ Prele Mammoth site sits at an unremarkable location. La Prele Creek flows continuously for more than $40 \mathrm{~km}$ from its head in the Laramie Range to its confluence with the North Platte $1.6 \mathrm{~km}$ downstream of the site, and there are no obvious point attractors adjacent to the site for human or 


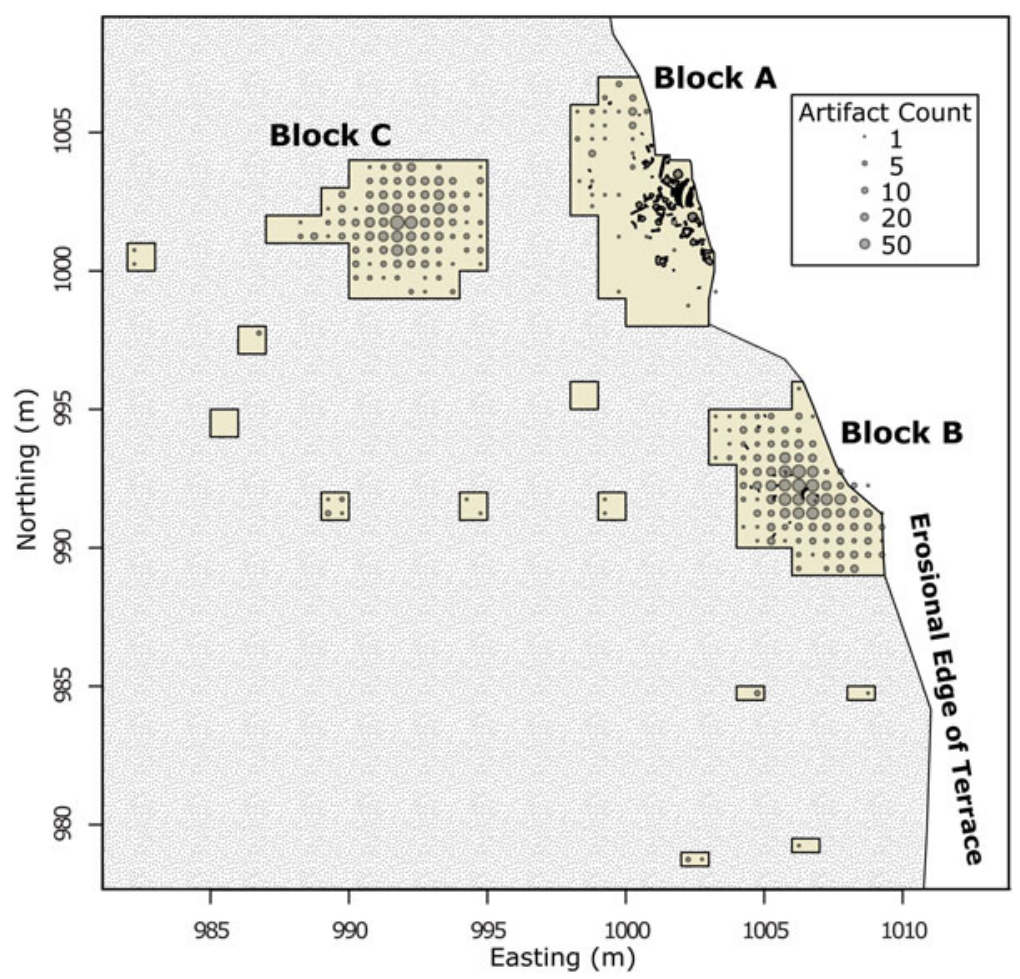

Figure 8. Frequency of lithics across the excavation blocks at the La Prele Mammoth site. Large piece-plotted bone is indicated including the 1987 bone bed in Block A. Block $\mathrm{C}$ screen processing is ongoing, so counts should be treated as preliminary. (Color online)

mammoth occupation, such as a spring. While we do not have a strong grasp of the age on the uppermost terrace deposits, we do know that the terrace continued to aggrade at least through the early Holocene and ceased before a cut and fill located above the mammoth was formed in the middle Holocene (Supplemental Text 1). No archaeological materials, other than Clovis, have been identified anywhere else in this sequence. It appears that the only human occupation of this locality occurred in the same stratigraphic position and in close spatial proximity to the mammoth. The chances of this spot on the landscape being the location of a natural mammoth mortality followed shortly by a Clovis occupation to never be used again seem exceedingly unlikely (Mackie 2019:52-87), especially at a time when human populations in Wyoming were very low (Kelly et al. 2013; Kornfeld et al. 2010). The most parsimonious explanation is that the mammoth remains and artifacts are associated.
Artifact Assemblage Attribute Analysis. A second source for redeposition of artifacts is the possibility that one of the close artifact clusters is the source of the Block A artifact assemblage. Although slope analysis and the gap in artifact density between areas suggest that this is not the case, we can test this hypothesis using the size of a sample of debitage from Block A $(n=41)$ and Block B ( $n=926$; Table 2). Since matrix picking and lithic analysis of Block $\mathrm{C}$ is ongoing, its artifact assemblage was not included in this analysis. If the materials from Block B

Table 2. Summary of Block A and Block B Debitage Dimensions.

\begin{tabular}{llllll}
\hline & \multicolumn{2}{c}{ Length $(\mathrm{mm})$} & & \multicolumn{2}{c}{ Mass $(\mathrm{g})$} \\
\cline { 2 - 3 } \cline { 6 - 6 } & Block A & Block B & & Block A & Block B \\
\hline Number & 39 & 166 & & 41 & 926 \\
Average & 8.156 & 6.942 & & 0.274 & 0.053 \\
Standard Deviation & 4.735 & 4.463 & & 0.685 & 0.611 \\
\hline
\end{tabular}




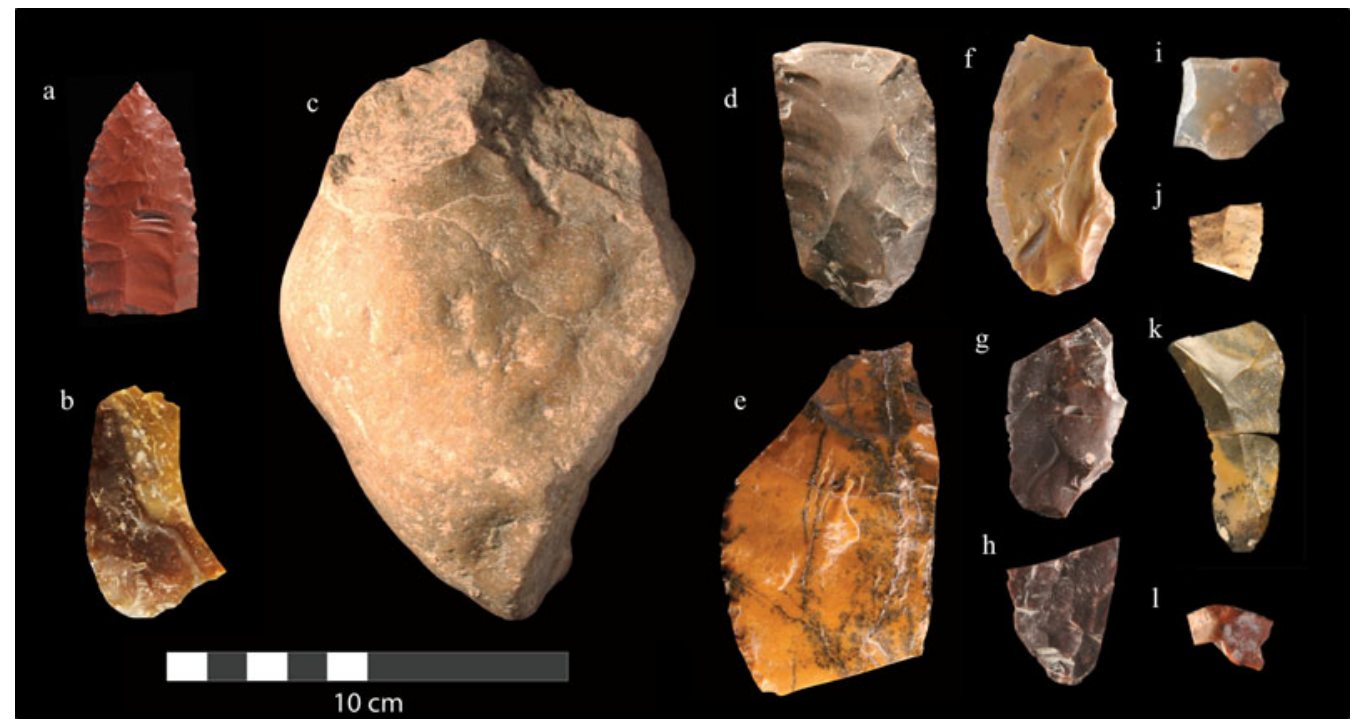

Figure 9. La Prele Mammoth site tool assemblage from (a) a test unit, (b) Block A, and (c-1) Block B: (a) partial Clovis point from approximately $20 \mathrm{~m}$ south of Block $A$; (b) flake tool recovered from within bone bed in Block A in 1987 excavations (FS 16); (c) cobble chopper (FS 354); (d) flake tool with graver (FS 1326); (e) flake tool with graver (FS 1547); (f) spokeshave/flake tool (FS 2970); (g) conjoined flake tool fragment (FS 3840 and FS 4399); (h) partial flake tool (FS 3055); (i) flake tool fragment (FS 3013); (j) flake tool fragment (FS 1349); (k) conjoined flake tool (FS 1917 and FS 1922); (1) partial burned endscraper (FS 4624). (Color online)

were redeposited to Block A, we would expect the Block A lithics to be smaller than the Block B lithics, as lighter lithics require less energy to be moved and would be preferentially transported (Byers et al. 2015; Sheppard and Kleindienst 1996). In fact, the opposite pattern is apparent, as a sample of Block A flakes are $(\bar{x}$ $=0.27 \mathrm{~g}, s=0.685, n=41$ ), on average, significantly heavier $(t=2.066, d f=40, p=.0226$, one sample) than Block B debitage $(\bar{x}=0.053, s=$ $0.611, n=926$ ).

\section{Direct Evidence of Association}

The final test to establish an association between the cultural activities and the mammoth remains is direct association. The lack of traditional indications of butchery, such as cutmarks, does not necessarily support a natural mammoth death. Ethnographic/ethnoarchaeological studies have shown that cutmarks may not be produced during carcass processing or could be obscured by weathering (e.g., Crader 1983; Frison 1989; Haynes 1988, 1991:303; Haynes and Klimowicz 2015). In fact, other accepted Clovis proboscidean kill/scavenge sites also lack clear butchery marks (Frison and Todd 1986; Hofman 2001; Sanchez et al. 2014). Additionally, the La Prele mammoth lacks many elements, including most of its appendicular elements, and many of the present faunal remains are weathered, obscuring any possible surface cutmarks (Byers 2002). It is unclear whether the absent elements are missing because they washed down La Prele Creek from the truncated portion of the site or whether they were moved to a yet unexcavated portion of the terrace. We assume that some portions of the mammoth were lost to site erosion based on the presence of rib and enamel plates on the terrace riser when the site was discovered in 1986. Instead we look to alternative methods to identify direct associations, specifically blood residue and lithic microwear analysis. Both analyses were run on the stone tools recovered from Blocks A and B, including the 1987 flake tool, a cobble tool, a Clovis point, and a set of flake tools (Figure 9). If the tools were used to butcher the mammoth, we would expect positive proboscidean blood residue results and microwear characteristics consistent with animal butchery. 
Table 3. Summaries of Crossover Immunoelectrophoresis and Microwear Lithic Analysis on Block A and Block B Stone Tools.

\begin{tabular}{|c|c|c|c|}
\hline Field Specimen & & Crossover Immunoelectrophoresis & \\
\hline Number & Artifact & Results & Microwear Results \\
\hline 16 & Flake tool & Elephant & Soft material butchery \\
\hline 354 & Cobble chopping tool & Elephant & Not analyzed \\
\hline 1326 & Flake tool with graver & Not analyzed & Soft material butchery, hide cutting \\
\hline 1349 & Flake tool fragment & Not analyzed & Possible butchery, longitudinal use \\
\hline 1547 & Flake tool with graver & Not analyzed & $\begin{array}{l}\text { Soft material butchery, hide cutting, } \\
\text { pouch polish }\end{array}$ \\
\hline 1917 and 1922 & Conjoined flake tool & Not analyzed & Butchery \\
\hline 2970 & Spokeshave & Bovine, elephant (weak) & Not analyzed \\
\hline 3013 & Flake tool fragment & Negative & Unutilized \\
\hline 3055 & Flake tool fragment & Swine & Indeterminate \\
\hline 3840 & $\begin{array}{l}\text { Flake tool (conjoins } \\
\text { 4399) }\end{array}$ & Horse, elephant (weak) & Butchery \\
\hline 4399 & $\begin{array}{l}\text { Flake tool (conjoins } \\
\text { 3840) }\end{array}$ & Horse, elephant (weak), sheep & Butchery \\
\hline 4624 & Scraper (burned) & Negative & Hide scraping \\
\hline 6862 & Clovis point & Negative & Projectile damage \\
\hline
\end{tabular}

Protein Residue Analysis. Protein blood residue analysis identifies plant and animal residues on flaked-and ground-stone lithic artifacts using immunological responses (Allen et al. 1995; Gerlach et al. 1996; Henrikson et al. 1998, 2017; Hyland et al. 1990; Kooyman et al. 2001; Petraglia et al. 1996; Shanks et al. 1999; Yohe et al. 1991). This method identifies the animal species artifacts may have contacted, although there are questions about its reliability (Eisele et al. 1995; Fiedel 1996). In this case, we used crossover immunoelectrophoresis (CIEP) to test archaeological residues using procedures developed by the Royal Canadian Mounted Police Serology Laboratory (1983). The samples were analyzed at the Laboratory of Archaeological Sciences located at California State University, Bakersfield. Reactions that produced particularly prominent or light precipitation lines were identified, respectively, as "strong" or "weak." Tests were repeated multiple times, and soil samples were tested to rule out any false positives. Eight family-level antisera (pronghorn antelope, bovine, Camelidae, Cervidae, Elephantidae, equine, Caprinae, and porcine) were tested on nine stone tools (Figure 9). Two tools and the Clovis point (Figure 9; Table 3) did not return a positive result with any antisera. Six other tools tested positive with at least one antiserum, including elephant, bovine, horse, swine, and sheep (Table 3). Multiple positive reactions for one flake tool could indicate repeated use of the same artifact or the species of materials used for hafting. Weak responses to elephant antiserum should be viewed with caution, as they could be the result of false positives, soil contamination, or protein degradation. While we do not have corollary evidence for all the species identified with CIEP, the strong reaction of two tools to proboscidean antiserum provides direct evidence of interaction between cultural materials and the mammoth remains (Table 3). Notably the two positive proboscidean reactions came from the flake tool recovered from within the bone bed in 1987 (Figure 9b) and the cobble chopping tool found in Block B (Figure 9c). The La Prele Mammoth cobble chopper is consistent with expedient cobble tools that have been found at other Clovis proboscidean kill sites (Frison and Todd 1986; Haury et al. 1959; Haynes and Huckell 2007), presenting another line of evidence for human use of the site.

Lithic Microwear Analysis. Since tool morphology is not always consistent with function (Jeske and Sterner-Miller 2015; Knutsson et al. 2015; Odell 1981; Rockwell 2017), lithic microwear studies aim to establish precise designations of tool functions using microscopic scarring patterns left on stone tools (Keeley 1974; 
Odell 1975). Low-powered microscopic (10$120 \times$ magnification) use-wear analysis was conducted on 10 tools from the La Prele Mammoth assemblage using a Nikon SMZ800 microscope (Odell and Odell-Vereecken 1980; Tringham et al. 1974). Microwear patterns from the La Prele tools were compared with a reference collection of tools with known function to identify activities and contact materials consistent with observed scarring patterns (Supplemental Text 2). When possible, contact materials were further refined by the description of polish and striations.

Eight of the 10 flake tools analyzed showed characteristics consistent with butchery of soft materials or hide working (Table 3; Supplemental Text 2; Supplemental Table 3). Two of these tools had corners reworked into graver tips that had scarring patterns and polish on the lateral margins of the flakes; this is consistent with butchery and hide preparation (Figure 9d-e; Supplemental Figures 2-3). One flake tool has notable wear on body arrises consistent with pouch polish, indicating that the tool may have been carried or curated for an extended duration (Figure 9e). The Clovis point was broken on its proximal end likely within the haft as ground basal edges are present (Figure 9a). While microwear analysis cannot attribute a specific species, the presence of wear consistent with butchery is what would be expected for a mammoth butchery site and generally correlates with the CIEP results.

\section{Conclusion}

To recap, a true association between cultural materials and the mammoth remains would be supported by (1) a mechanism for vertical dispersal, (2) little evidence for horizontal movement, (3) bone and artifacts showing similar distributions, and (4) evidence of interaction between humans and the mammoth remains. There is support for all four hypotheses based on the geologic context of the site, observed spatial distributions, artifact assemblage attributes, and tests for direct associations between the cultural materials and the mammoth remains. The minimal slope of the paleosurface makes artifact redeposition unlikely, while the bioturbation provides a parsimonious explanation for the elevation discrepancies identified by Byers (2002). The overlapping dates (Table 1), similar vertical distribution of artifacts (Figures 4 and 6), and spatial distributions (Figure 8) support the hypothesis that Blocks A, B, and C were contemporaneously occupied. The presence of distinct artifact clusters with minimal "smearing" by postdepositional processes indicates intact horizontal artifact distributions. The CIEP and lithic microwear analysis are consistent with animal butchery and, in the case of the CIEP results, directly link some artifacts to the mammoth remains (Table 3). Finally, it seems highly unlikely that two closely timed events (a mammoth dying and a Clovis occupation) would occur in such a small time period without being associated, particularly since the locality was never occupied again.

Generally, archaeologists use three criteria to evaluate the evidence for human-killed/ scavenged megafauna: (1) contemporaneity, (2) association, and (3) utilization (Grayson and Meltzer 2002, 2015; Haynes and Stanford 1984). In the case of the La Prele Mammoth site, contemporaneity is supported by new radiocarbon dates and consistent stratigraphic association. The close spatial association of mammoth remains and artifacts provides a case for a strong association, while the new understanding of geologic setting offers a reasonable explanation for the previously raised doubts. Although this site does not have any traditional indicators of direct use (e.g., cutmarks), the identified tools have tested positive for proboscidean blood antigens and have lithic microwear consistent with animal butchery. We feel that the site rises to the "consonance of data" (Haynes and Stanford 1984:220) required to fulfill these three criteria. We propose that the La Prele Mammoth site is at least the sixteenth case of culturally associated megafauna kill/scavenge sites (Grayson and Meltzer 2015).

La Prele Mammoth demonstrates the value of reinvestigation of previously doubted archaeological kill/scavenge sites. Without further excavation and analysis, the site would have continued to be another doubted case of a human-mammoth association. As it represents the addition of another site to debates where the number of sites is often presented as evidence 
against (e.g., Grayson 2001; Haynes and Stanford 1984; Meltzer 1986; Wroe et al. 2004) or for (Surovell and Grund 2012; Surovell and Waguespack 2008) Pleistocene overkill and Clovis large game specialization, La Prele serves as a reminder that there are likely other sites that are currently underinvestigated to be considered reliable enough to include in counts of terminal Pleistocene megafaunal kill/ scavenge sites. The traditional three-part criteria (contemporaneity, direct association, and use) employed to evaluate Clovis kill/scavenge sites are reasonable but require a burden of proof that is not possible without significant investigation and careful excavation. Byers's (2002) doubt was reasonable given the limited artifact assemblage and minimal geologic context available. The results of new excavations at the $\mathrm{La}$ Prele Mammoth site should encourage the investigation of other proboscidean sites that are currently in limbo due to insufficient reporting or excavation.

Clarification of the number and type of proboscidean death/butchery sites can contribute to a variety of debates in Paleoindian archaeology, including overkill, Clovis subsistence, and the social and economic implications of procuring large animals. As at least the sixteenth identified extinct megafauna processing site, La Prele, and its expanded assemblage, is an important contribution to the Clovis literature. The presence of multiple artifact concentrations contemporaneously occupied during mammoth butchery is uncommon, with only one other case (or possibly two) reported (Haynes and Huckell 2007; Sanchez et al. 2014). Further excavation and analysis of these activity areas is ongoing and will contribute to our understanding of the full suite of activities that took place during megafauna butchery in the terminal Pleistocene.

Acknowledgments. We thank Jack and Zach Amen for allowing access to the site. We are very grateful to James and Shirley Baker for running the backhoe, providing various site construction materials, and fixing all the things we have broken over the years. Without countless excavators including volunteers, undergraduate and graduate students, members of the Northern Arapahoe Tribe, Rich Adams, and four years of the University of Wyoming Archaeological Field School (2014-2017), this project would not have been possible. Laboratory analysis would have taken significantly longer without the help of volunteers including Paul Sanders, Sandra Zarzycka, Rebecca Mattson, and a team of additional students. Thank you goes to the University of Wyoming Archaeological Repository for allowing us access to the 1987 collection and to Sarah Allaun D'Lopez for translating the Spanish abstract. Support for this project was provided by the Frison Institute of Archaeology and Anthropology, the University of Wyoming Archaeological Field School, the Shlemon Center for Quaternary Studies, the National Geographic Society (\#9896-19), the Wyoming Cultural Trust Fund, and the Quest Archaeological Research Program. We thank Thomas Jennings, Lynn Gamble, and three anonymous reviewers for their comments on an earlier draft of this manuscript.

Data Availability Statement. All data and collections associated with the La Prele Mammoth site are housed at the University of Wyoming Department of Anthropology in Laramie, Wyoming.

Supplemental Materials. For supplementary material accompanying this essay, visit https://doi.org/10.1017/aaq.2020.8.

Supplemental Text 1. Description of geologic context for the La Prele Mammoth site.

Supplemental Text 2. Lithic microwear methods, blind test results, and wear descriptions for La Prele Mammoth (LPM) tools.

Supplemental Table 1. Radiocarbon dates from excavations (Blocks A and B) and Trench 1 at the La Prele Mammoth site.

Supplemental Table 2. Optically stimulated luminescence dates from Trench 1.

Supplemental Table 3. Microwear characteristics for tools listed in Table 3.

Supplemental Figure 1. Profile of Trench 1 from 2014 including all optically stimulated luminescence (OSL) and radiocarbon dates. Note that OSL dates are presented in calendar years before present while radiocarbon dates are presented in radiocarbon years before present.

Supplemental Figure 2. Examples of lithic microwear patterns observed on the La Prele Mammoth (LPM) tool assemblage and the polar coordinate system for identifying use locations.

Supplemental Figure 3. Examples of unmodified and retouched tools from an experimental collection.

\section{Notes}

1. Originally, 12 flakes were identified in cast sediments (Byers 2002); however, when we reviewed the original artifact assemblage, only seven could be identified as indisputable artifacts based on traditional debitage characteristics (e.g., sharp edges, platforms, bulb of percussion).

2. Based on the positioning of the original (1987) unit nails found in 2014, grid northing and easting could be reestablished with high confidence. Unfortunately, there was little means for establishing elevational control other than comparing artifact back plots and estimating the elevation of the floor of the 1987 excavations. As a result, we are less confident in our vertical reconstruction. 


\section{References Cited}

Adovasio, James, and Jake Page

2009 The First Americans: In Pursuit of Archaeology's Greatest Mystery. Random House, New York.

Albanese, John

2000 Reconnaissance Geological Study of the Fetterman Mammoth Site (18CO1401) Converse County, Wyoming. Manuscript on file, Office of the Wyoming State Archaeologist, Laramie.

Allen, Jane, Margaret E. Newman, Mary Riford, and Gavin H. Archer

1995 Blood and Plant Residues on Hawaiian Stone Tools from Two Archaeological Sites in Upland Kāne'ohe, Ko'olau Poko District, O'ahu Island. Asian Perspectives 34:283-302.

Byers, David A.

2002 Taphonomic Analysis, Associational Integrity, and Depositional History of the Fetterman Mammoth, Eastern Wyoming, USA. Geoarchaeology 17:417-440. Byers, David A., Elise Hargiss, and Judson Byrd Finley 2015 Flake Morphology, Fluvial Dynamics, and Debitage Transport Potential. Geoarchaeology 30:379-392.

Cannon, Michael D., and David J. Meltzer

2004 Early Paleoindian Foraging: Examining the Faunal Evidence for Large Mammal Specialization and Regional Variability in Prey Choice. Quaternary Science Reviews 23:1955-1987.

2008 Explaining Variability in Early Paleoindian Foraging. Quaternary International 191:5-17.

Chatters, James C., James W. Brown, Steven Hackenberger, Patrick McCutcheon, and Jonathan Adler

2017 Calcined Bone as a Reliable Medium for Radiocarbon Dating: A Test Using Paired North American Samples. American Antiquity 82:593-608.

Crader, Diana C

1983 Recent Single-Carcass Bone Scatters and the Problem of "Butchery" Sites in the Archaeological Record. In Animals and Archaeology: Hunters and Their Prey, edited by Juliet Clutton-Brock and Caroline Grigson, pp. 107-141. Bar International Series 163. British Archaeological Reports, Oxford.

Devièse, Thibaut, Thomas W. Stafford Jr., Michael R. Waters, Crista Wathen, Daniel Comeskey, Lorena Becerra-Valdivia, and Thomas Higham

2018 Increasing Accuracy for the Radiocarbon Dating of Sites Occupied by the First Americans. Quaternary Science Reviews 198:171-180.

Eisele, Judith A., Don D. Fowler, Gary Haynes, and Roger A. Lewis

1995 Survival and Detection of Blood Residues on Stone Tools. Antiquity 69:36-46.

Fanning, Patricia, and Simon Holdaway

2001 Stone Artifact Scatters in Western NSW, Australia: Geomorphic Controls on Artifact Size and Distribution. Geoarchaeology 16:667-686.

Fiedel, Stuart

1996 Blood from Stones? Some Methodological and Interpretive Problems in Blood Residue Analysis. Journal of Archaeological Science 23:139-147.

Figgins, Jesse Dade

1933 A Further Contribution to the Antiquity of Man in America. Colorado Museum of Natural History Proceedings 2(2):4-11.

Frison, George C.

1989 Experimental Use of Clovis Weaponry and Tools on African Elephants. American Antiquity 54:766-784.
Frison, George C., and Lawrence C. Todd

1986 Colby Mammoth Site: Taphonomy and Archaeology of a Clovis Kill in Northern Wyoming. University of New Mexico Press, Albuquerque.

Gerlach, S. Craig, Margaret Newman, Edward J. Knell, and Edwin S. Hall Jr.

1996 Blood Protein Residues on Lithic Artifacts from Two Archaeological Sites in the De Long Mountains, Northwestern Alaska. Arctic 49:1-10.

Giusti, Domenico, Vangelis Tourloukis, George E. Konidaris, Nicholas Thompson, Panagiotis Karkanas, Eleni Panagopoulou, and Katerina Harvati

2018 Beyond Maps: Patterns of Formation Processes in the Middle Pleistocene Open-Air Site of Marathousa 1, Megalopolis Basin, Greece. Quaternary International 497:137-153.

Grayson, Donald K.

1984 Archaeological Associations with Extinct Pleistocene Mammals in North America. Journal of Archaeological Science 11:213-221.

2001 The Archaeological Record of Human Impacts on Animal Populations. Journal of World Prehistory 15:1-68.

Grayson, Donald K., and David J. Meltzer

2002 Clovis Hunting and Large Mammal Extinction: A Critical Review of the Evidence. Journal of World Prehistory 16:313-359.

2015 Revisiting Paleoindian Exploitation of Extinct North American Mammals. Journal of Archaeological Science 56:177-193

Gregg, Susan A., Keith W. Kintigh, and Robert Whallon

1991 Linking Ethnoarchaeological Interpretation and Archaeological Data. In The Interpretation of Archaeological Spatial Patterning, edited by Ellen M. Kroll and T. Douglas Price, pp. 149-196. Springer, Boston.

Haury, Emil W., Edwin Booth Sayles, and William W. Wasley

1959 The Lehner Mammoth Site, Southeastern Arizona. American Antiquity 25:2-30.

Haynes, C. Vance

1969 The Earliest Americans. Science 166(3906):709715 .

Haynes, Gary

1988 Spiral Fractures, Cutmarks, and Other Myths about Early Bone Assemblages. In Early Human Occupation in Far Western North America: The Clovis-Archaic Interface, edited by Judith A. Willig, C. Melvin Aikens, and John Lee Fagan, pp. 145-151. Anthropological Papers No. 21. Nevada State Museum, Carson City.

1991 Mammoths, Mastodonts, and Elephants: Biology, Behavior, and the Fossil Record. Cambridge University Press, Cambridge.

2002 The Early Settlement of North America: The Clovis Era. Cambridge University Press, Cambridge.

2007b Rather Odd Detective Stories: A View of Some Actualistic and Taphonomic Trends in Paleoindian Studies. In Breathing Life into Fossils: Taphonomic Studies in Honor of C. K. (Bob) Brain, edited by Travis R. Pickering, Kathy Schick, and Nicholas Toth, pp. 2535. Stone Age Institute, Gosport, Indiana.

2007a One Way to Understand Mammoths: Lessons from Actualistic Studies of Modern Elephants. In Human and Faunal Relationships Reviewed: An Archaeozoological Approach, edited by Eduardo Corona M. and J. Arroyo-Cabrales, pp. 81-94. BAR International Series 1627. British Archaeological Reports, Oxford. 
Haynes, C. Vance, and Bruce B. Huckell

2007 Murray Springs: A Clovis Site with Multiple Activity Areas in the San Pedro Valley, Arizona. University of Arizona Press, Tucson.

Haynes, Gary, and Jarod M. Hutson

2013 Clovis-Era Subsistence: Regional Variability, Continental Patterning. In Paleoamerican Odyssey, edited by Kelly E. Graf, Caroline V. Ketron, and Michael R. Waters, pp. 293-309. Texas A\&M University Press, College Station.

Haynes, Gary, and Janis Klimowicz

2015 Recent Elephant-Carcass Utilization as a Basis for Interpreting Mammoth Exploitation. Quaternary International 359:19-37.

Haynes, Gary, and Kathryn E. Krasinski

2010 Taphonomic Fieldwork in Southern Africa and Its Application in Studies of the Earliest Peopling of North America. Journal of Taphonomy 8(2-3):181202.

Haynes, Gary, and Dennis Stanford

1984 On the Possible Utilization of Camelops by Early Man in North America. Quaternary Research 22:216230.

Henrikson, Lael Suzann, David Byers, Robert M. Yohe II, and Matt De Carlo

2017 Folsom Mammoth Hunters? The Pleistocene Assemblage at Owl Cave (10BV30) Wasden Site, Idaho. American Antiquity 82:575-592.

Henrikson, Lael Suzann, Robert M. Yohe, Margaret E. Newman, and Mark Druss

1998 Freshwater Crustaceans as an Aboriginal Food Resource in the Northern Great Basin. Journal of California and Great Basin Anthropology 20:72-87.

Hofman, Jack L.

2001 Mehl's Dilemma: Paleomortology and Interpretation of the Clovis Mammoth Association at Domebo, Oklahoma. In Proceedings of the International Conference on Mammoth Site Studies, edited by D. L. West, pp. 95-103. Publications in Anthropology 22. University of Kansas, Department of Anthropology, Lawrence.

Hyland, David C., Jean M. Tersak, James M. Adovasio, and Michael I. Siegel

1990 Identification of the Species of Origin of Residual Blood on Lithic Material. American Antiquity 55:104 112.

Jeske, Robert J., and Katherine M. Sterner-Miller

2015 Microwear Analysis of Bipolar Tools from the Crescent Bay Hunt Club Site (47JE904). Lithic Technology 40:366-376.

Keeley, Lawrence H.

1974 Technique and Methodology in Microwear Studies: A Critical Review. World Archaeology 5:323-336.

Kelly, Robert L., Todd A. Surovell, Bryan N. Shuman, and Geoffrey M. Smith

2013 A Continuous Climatic Impact on Holocene Human Population in the Rocky Mountains. Proceedings of the National Academy of Sciences of the United States of America 110:443-447.

Knutsson, Helena, Kjel Knutsson, Noora Taipale, Miikka Tallavaara, and Kim Darmark

2015 How Shattered Flakes Were Used: Micro-wear Analysis of Quartz Flake Fragments. Journal of Archaeological Science: Reports 2:517-531.

Kooyman, Brian, Margaret E. Newman, Christine Cluney, Murray Lobb, Shayne Tolman, Paul McNeil, and L. V. Hills
2001 Identification of Horse Exploitation by Clovis Hunters Based on Protein Analysis. American Antiquity 66:686-691.

Kornfeld, Marcel

2007 Are Paleoindians of the Great Plains and Rockies Subsistence Specialists? In Foragers of the Terminal Pleistocene in North America, edited by Renee B. Walker and Boyce N. Driskell, pp. 32-58. University of Nebraska Press, Lincoln.

Kornfeld, Marcel, George C. Frison, and Mary Lou Larson

2010 Prehistoric Hunter-Gatherers of the High Plains and Rockies. 3rd ed. Left Coast Press, Walnut Creek, California.

Kreutzer, Lee Ann

1988 Megafaunal Butchering at Lubbock Lake, Texas: A Taphonomic Reanalysis. Quaternary Research 30:221231.

Long, Austin, and Bruce Rippeteau

1974 Testing Contemporaneity and Averaging Radiocarbon Dates. American Antiquity 39:205-215.

Lyman, R. Lee

1994 Vertebrate Taphonomy. Cambridge University Press, Cambridge.

Mackie, Madeline E.

2019 Paleoindian-Proboscidean Interactions in the Terminal Pleistocene. PhD dissertation, Anthropology, University of Wyoming, Laramie.

Mackie, Madeline E., Todd A. Surovell, Spencer Pelton, Matthew O'Brien, Robert L. Kelly, George C. Frison, Robert M. Yohe, Steve Teteak, Beth Shapiro and Joshua D. Kapp

2020 Spatial Analysis of a Clovis Hearth Centered Activity Area at the La Prele Mammoth Site, Converse County, Wyoming. In Diversity in Open Air Site Structure Across the Pleistocene/Holocene Boundary, edited by Kristen Carlson and Leland C. Bement. University Press of Colorado, Louisville, Colorado, in press.

Meltzer, David J.

1986 Pleistocene Overkill and the Associational Critique. Journal of Archaeological Science 13:51-60.

2015a The Great Paleolithic War: How Science Forged an Understanding of America's Ice Age Past. University of Chicago Press, Chicago.

2015b Pleistocene Overkill and North American Mammalian Extinctions. Annual Review of Anthropology 44:33-53.

Meltzer, David J., and Jim I. Mead

1985 Dating Late Pleistocene Extinctions: Theoretical Issues, Analytical Bias, and Substantive Results. In Environments and Extinctions: Man in Late Glacial North America, edited by Jim I. Mead and David Meltzer, pp. 145-173. Center for the Study of Early Man, Orono, Maine.

Odell, George H.

1975 Micro-wear in Perspective: A Sympathetic Response to Lawrence H. Keeley. World Archaeology 7:226-240.

1981 The Morphological Express at Function Junction: Searching for Meaning in Lithic Tool Types. Journal of Anthropological Research 37:319-342.

Odell, George H., and Frieda Odell-Vereecken

1980 Verifying the Reliability of Lithic Use-Wear Assessments by "Blind Tests": The Low-Power Approach. Journal of Field Archaeology 7:87-120.

Petraglia, Michael, Dennis Knepper, Petar Glumac, Margaret Newman, and Carole Sussman

1996 Immunological and Microwear Analysis of 
Chipped-Stone Artifacts from Piedmont Contexts. American Antiquity 61:127-135.

Poesen, Jean W., Bas van Wesemael, Kristin Bunte, and Albert Sole Benet

1998 Variation of Rock Fragment Cover and Size along Semiarid Hillslopes: A Case-Study from Southeast Spain. Geomorphology 23:323-335.

Reimer, Paula J., Edouard Bard, Alex Bayliss, J. Warren Beck, Paul G. Blackwell, Christopher Bronk Ramsey, Caitlin E. Buck, Hai Cheng, R. Lawrence Edwards, and Michael Friedrich

2013 IntCal13 and Marine13 Radiocarbon Age Calibration Curves 0-50,000 Years cal BP. Radiocarbon 55:1869-1887.

Rockwell, Heather M.

2017 Microwear Analysis of the Potter Site and Its Ability to Alter Functional Interpretations. Archaeology of Eastern North America 45:161-173.

Royal Canadian Mounted Police

1983 Methods Manual, Serology Section, Ottawa, Ontario.

Sanchez, Guadalupe, Vance T. Holliday, Edmund P. Gaines, Joaquín Arroyo-Cabrales, Natalia Martínez-Tagüeña, Andrew Kowler, Todd Lange, Gregory W. L. Hodgins, Susan M. Mentzer, and Ismael Sanchez-Morales

2014 Human (Clovis)-Gomphothere (Cuvieronius sp.) Association 13,390 Calibrated yBP in Sonora, Mexico. Proceedings of the National Academy of Sciences of the United States of America 111:10972-10977.

Saunders, Jeffrey J., and Edward B. Daeschler

1994 Descriptive Analyses and Taphonomical Observations of Culturally-Modified Mammoths Excavated at "The Gravel Pit," near Clovis, New Mexico in 1936. Proceedings of the Academy of Natural Sciences of Philadelphia 145:1-28.

Shanks, Orin C., Marcel Kornfeld, and Dee Dee Hawk

1999 Protein Analysis of Bugas-Holding Tools: New Trends in Immunological Studies. Journal of Archaeological Science 26:1183-1191.

Sheppard, Peter J., and Marine R. Kleindienst

1996 Technological Change in the Earlier and Middle Stone Age of Kalambo Falls (Zambia). African Archaeological Review 13:171-196.

Surovell, Todd A., and Brigid S. Grund

2012 The Associational Critique of Quaternary Overkill and Why It Is Largely Irrelevant to the Extinction Debate. American Antiquity 77:672-687.

Surovell, Todd A., and Nicole M. Waguespack

2008 How Many Elephant Kills Are 14? Clovis Mammoth and Mastodon Kills in Context. Quaternary International 191:82-97.

Surovell, Todd A., and Nicole M. Waguespack

2009 Human Prey Choice in the Late Pleistocene and Its
Relation to Megafaunal Extinctions. In American Megafaunal Extinctions at the End of the Pleistocene, edited by Gary Haynes, pp. 77-105. Springer, New York.

Todd, Lawrence C.

1987 Taphonomy of the Horner II Bone Bed. In The Hor ner Site: The Type Site of the Cody Cultural Complex, edited by George C. Frison and Lawrence C. Todd, pp. 107-198. Academic Press, Orlando, Florida.

Todd, Lawrence C., and David J. Rapson

1999 Formational Analysis of Bison Bonebeds and Interpretation of Paleoindian Subsistence. In Le Bison: Gibier et Moyen de Subsitance de homes du Paleolithique aux Paleoindiens des Grandes Plaines, edited by Jean-Philip Brugal, Francine David, James G. Enloe, and Jacques Jaubert, pp. 480-499. Actes du Colloque International, Toulouse, France.

Tringham, Ruth, Glenn Cooper, George Odell, Barbara Voytek, and Anne Whitman

1974 Experimentation in the Formation of Edge Damage: A New Approach to Lithic Analysis. Journal of Field Archaeology 1:171-196.

Waguespack, Nicole M.

2013 Pleistocene Extinctions: The State of Evidence and the Structure of Debate. In Paleoamerican Odyssey, edited by Kelly E. Graf, Caroline V. Ketron, and Michael R. Waters, pp. 311-319. Texas A\&M University Press, College Station.

Waguespack, Nicole M., and Todd A. Surovell

2003 Clovis Hunting Strategies, or How to Make Out on Plentiful Resources. American Antiquity 68:333-352.

Walker, Danny N., George C. Frison, David Darlington, Richard Reider, William R. Latady, and Mark E. Miller

1988 The Hinrichs Mammoth Site, Converse County, Wyoming. Paper presented at the 10th Biennial Meeting of the American Quaternary Association, Amherst, Massachusetts.

Waters, Michael R., and Thomas W. Stafford

2007 Redefining the Age of Clovis: Implications for the Peopling of the Americas. Science 315(5815):1122-1126.

Wroe, Stephen, Judith Field, Richard Fullagar, and Lars S. Jermin

2004 Megafaunal Extinction in the Late Quaternary and the Global Overkill Hypothesis. Alcheringa 28:291331.

Yohe, Robert M., Margaret E. Newman, and Joan S. Schneider 1991 Immunological Identification of Small-Mammal Proteins on Aboriginal Milling Equipment. American Antiquity 56:659-666.

Submitted September 13, 2019; Revised January 17, 2020;

Accepted January 24, 2020 